\title{
Citrus Cultivars and Production in Morocco
}

\author{
Mohamed El-Otmani \\ Department de Horticulture, Institut Agronomique et Vétérinaire Hassan II, Complexe Horticole d'Agadir, B.P. \\ 121 Ait Melloul, Agadir, Morocco \\ Charles W. Coggins, Jr. \\ Department of Botany and Plant Sciences, University of California, Riverside, CA 92521 \\ Andrew Duymovic \\ U.S. Department of Agriculture, Foreign Agricultural Service, Washington, DC 20251
}

\section{HISTORY}

Early in this century, the Moroccan citrus industry was very small, with plantings of $\approx 625$ ha in 1920 , mostly owned by Moroccan farmers (ASPAM, 1986). Major plantings started in the late 1930s, when the French established intensively managed groves. By 1940 , the citrus area totaled $\approx 12,500 \mathrm{ha}$ and, by $1960, \approx 55,000$ ha. At present, official figures indicate an area of 71,300 ha, all owned by Moroccan nationals (MARA, 1988). The number of citrus farmers is estimated to be $\approx 7400$ (ASPAM, 1986).

\section{PRESENT SITUATION : TONNAGE AND AREAS OF PRODUCTION}

Available statistics for 1987-88 indicate a total production of $\approx 1,233,500$ t (MARA, 1988) of more than 30 cultivars of citrus (ASPAM, 1986). In 1987-88, Morocco was the 10th largest citrus producer in the world (FAO, 1989a) and the third largest exporter of fresh citrus. It ranked second to Spain in export of oranges and tangerines. A recent FAO report (FAO, 1989b) projects a $48 \%$ increase in orange production and a $10 \%$ increase in tangerine production between 1987 and 2000. This projected increase is consistent with Moroccan government policy, which provides financial incentives for such expansion (FAO, 1989c).

Groves are located in six major areas (Fig. 1 , Table 1). The Seuss valley represents $31 \%$ of the total area and $34 \%$ of the total production, whereas the Gharb provides $24 \%$ of the total hectarage and $35 \%$ of the national tonnage. In 1964, the Gharb accounted for $52 \%$ of the total area, while the Seuss had only $12 \%$ (Burke, 1967). During the period of 1964-88, the area in the Gharb declined somewhat, while that of the Seuss and the Tadla tripled; that of the Oriental region doubled, whereas that of the Haouz remained reasonably constant. Minor production areas include Loukkos and the regions of Fes, Meknes, and Casablanca.

Received for publication 10 Oct. 1989. The cost of publishing this paper was defrayed in part by the payment of page charges. Under postal regulations, this paper therefore must be hereby marked advertisement solely to indicate this fact.

\section{CLIMATE}

Moroccan citrus areas lie between lat. $30^{\circ}$ and $35^{\circ} \mathrm{N}$, within which limits producing districts are localized because of climate, topography, and water availability. The Gharb has alluvial and clay soils. It has some of the oldest citrus groves in the country because it was the first region where citrus was grown intensively. It is located at an altitude of $32 \mathrm{~m}$ and has a humid climate with an average rainfall of 500 to $600 \mathrm{~mm} \cdot$ year $^{-1}$. Because of heavy soils, flat terrain, low elevation, and relatively high water table, heavy rainfall creates anaerobic soil conditions, which hasten tree decline. In addition, rains are-common from September to November and coincide with the maturation of ' $\mathrm{Cle}$ mentine' mandarin. Such rains are associ- ated with puffy fruit and rapid fruit senescence. Thus, this area is not favorable for early cultivars.

Seuss is the southernmost citrus region of Morocco. It is an arid area characterized by low rainfall $\left(230 \mathrm{~mm} \cdot \mathrm{year}^{-1}\right.$, with temperatures as high as $46 \mathrm{C}$ in the summer and as low as $0 \mathrm{C}$ in the winter. The humidity is low and the number of sunny days (average of 350 days of sunshine/year) exceeds those of other citrus-producing areas. Occasionally, strong hot desert winds, called "chergui", blow from the southeast and make the air even dryer. Irrigation water is mostly pumped from wells. Under this climate, early cultivars, such as 'Clementine', do very well.

The Tadla district is located in the interior and has a semi-arid climate. It lies 400 to $500 \mathrm{~m}$ above sea level and has an average

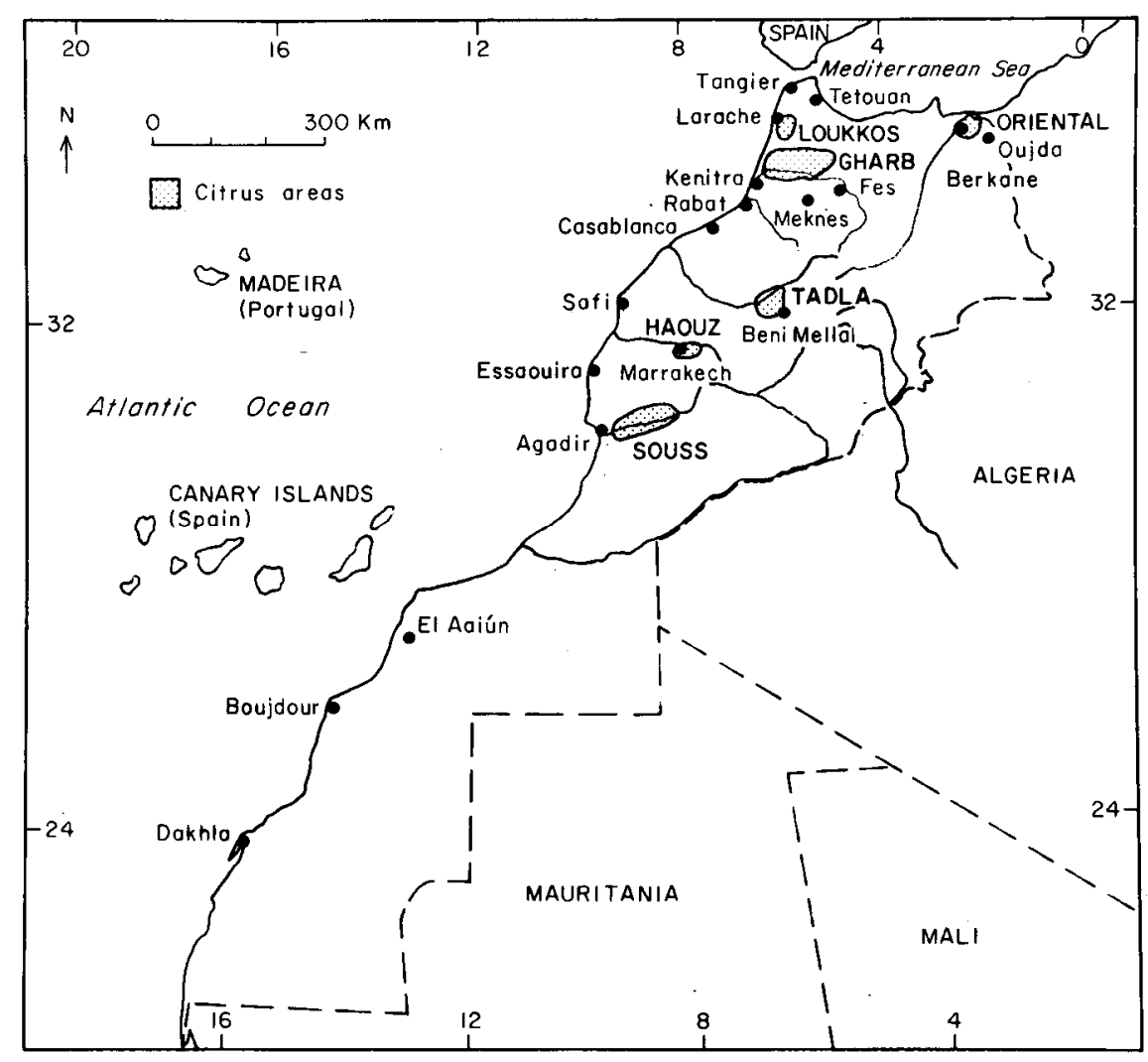

Fig. 1. Citrus growing regions of Morocco. 
rainfall of $360 \mathrm{~mm} \cdot \mathrm{year}^{-1}$. Spring frosts occur and minima and maxima are -1 and $44 \mathrm{C}$, respectively. Irrigation water comes primarily from reservoirs. Under these conditions, citrus does very well in years when there is little or no frost damage.

The Oriental district is located in the northeast region near the Mediterranean Sea. The climate is very favorable to early cultivars, especially 'Clementine' mandarin. The average rainfall is $\approx 350 \mathrm{~mm} \cdot$ year $^{-1}$. Irrigation water is mostly from reservoirs. Salt is becoming a limiting factor for citriculture in some parts of the district.

The Haouz district is the driest and hottest citrus area of Morocco. In this arid area, rainfall averages $<250 \mathrm{~mm} \cdot \mathrm{year}^{-1}$, humidity is relatively low, and the average annual temperature is $>25 \mathrm{C}$. Irrigation water comes from reservoirs and wells. Hot "chergui" winds are also common and, because of its inland location, summer temperatures are a few degrees higher and winter temperatures a few degrees lower than those mentioned for Seuss.

The Loukkos area has a humid climate with an average rainfall of $700 \mathrm{~mm} \cdot \mathrm{year}^{-1}$. There, citrus is grown mostly on sandy soils.

\section{CULTIVARS AND ROOTSTOCKS}

Because Morocco is reasonably free of tristeza (at least the virulent strain), citrus trees are almost exclusively budded onto sour orange (Citrus aurantium L.). This rootstock is well-adapted to the various climatic zones and is highly compatible with all of the cultivars grown in the country. A few plantings are on 'Troyer' citrange [C. sinensis (L.) Osb. $\times$ Poncirus trifoliata (L.) Raf.], but mostly for experimental purposes.

A recent national survey indicates the presence of at least 30 different commercial cultivars (ASPAM, 1986), of which the most important are shown in Table 2. 'Clementine' mandarin occupies the largest area (32\% of the total), followed by the 'Valencia' (30\%) and the navel $(25 \%)$ oranges. The first is a seedless cultivar due to its self-incompatibility. It is an easy peeler with thin skin, strong aroma, excellent quality, and it matures early (mid-September to early October). However, the fruit keeps poorly, especially in rainy years, and it is very susceptible to mechanical damage, and, subsequently, to decay via wounds from harsh handling. In addition, it is difficult to transport this cultivar successfully. Several clones have been selected (Devaux, 1981) for earliness or lateness to avoid overproduction and market saturation by the standard clone. These clones have mostly arisen as mutations of the common 'Clementine' or of each other. Early cultivars include 'Carte Noire', which often has excessive fruit set, resulting in small fruit size. It matures as early as mid-September. The 'G.P.' clone matures a bit later and is harvested before the common type. Late-ripening types include the 'Nour', maturing in late January to early February, the 'Late January Azemmour', the 'Late January Rabat', and the 'Late April', all of which have a thicker, firmer peel, allowing them to with- stand long on-tree storage as well as longdistance transportation. Also, these late-maturing strains have fewer rind blemishes than the common strain, probably a result of their thicker and firmer peels. These strains are being tested in various regions to determine their adaptation.

By extending the growing season and varying the cultivar profile, the Moroccan citrus industry is expected to be more competitive in the international market by filling in the existing production gaps. The 'Wilking' mandarin used to be an important cultivar in Morocco because of its large size, good eating and keeping quality, and lateness in production. However, it is highly seedy and pollinates the 'Clementine'. Since consumers spurn seedy fruit, all of the 'Wilking' plantings have been destroyed and, by law, planting 'Wilking' mandarin is banned. Other minor mandarins, and hybrids thereof, include 'Ortanique', 'Temple', and 'Monreal'.

The most common orange is 'Valencia'. It is a firm fruit with good keeping quality and it matures late (March-April). It constitutes $>40 \%$ of the total tonnage produced from only $30 \%$ of the total national citrus hectarage (Table 2). 'Washington' navel orange is the most important cultivar of the navel group. It matures early (November), keeps well, and is of excellent eating quality. Blood oranges are still common, although they occupy only $6 \%$ of the total area and production. The main blood cultivar is 'Washington Sanguine', which has only low concentrations of anthocyanin pigments in the endocarp and even lower concentrations in the peel. It is very juicy with a thin peel and is of excellent quality. It matures in January-February. Other minor orange cultivars include 'Salustiana', 'Hamlin', 'Navelina', 'Sanguinelli', and 'Verna'. Other citrus types include lemons (<1000 ha, mostly 'Eureka') and grapefruit (< 150 ha) (MARA, 1988).

The most recent survey (ASPAM, 1986) shows that $50 \%$ of the trees are between 10 and 24 years old, $21 \%$ are 25 to 34 years old, but only $12 \%$ are $>35$ years old (Table $3)$. The youngest groves are the 'Clementine' ( $82 \%$ are $<24$ years old) and the oldest are the blood oranges $(52 \%$ are $>25$ years old). However, the latter occupy a small percentage of the total hectarage and, due to

Table 1. Moroccan citrus area and production, by region $(1987-88){ }^{2}$

\begin{tabular}{llcccr}
\hline \hline & & \multicolumn{2}{c}{ Total area } & \multicolumn{2}{c}{ Total production } \\
\cline { 3 - 4 } Region & Major city & ha & $\%$ & t $(\times 1000)$ & $\%$ \\
\hline Souss & Agadir & 21,870 & 31 & 418.0 & 34 \\
Gharb & Kenitra & 17,100 & 24 & 426.0 & 35 \\
Oriental & Berkane & 10,740 & 15 & 136.0 & 11 \\
Tadla & Beni-Mellal & 8,970 & 12 & 116.5 & 9 \\
Haouz & Marrakech & 4,820 & 7 & 45.7 & 4 \\
Loukkos & Larache & 2,260 & 3 & 42.8 & 3 \\
Other & $\ldots .$. & 5,550 & 8 & 48.5 & 4 \\
Total & & 71,310 & 100 & 1233.5 & 100 \\
\hline
\end{tabular}

${ }^{z}$ Data from MARA, 1988.

Table 2. Moroccan citrus area and production, by type (1987-88). ${ }^{2}$

\begin{tabular}{lcccrr}
\hline & \multicolumn{2}{c}{ Area } & & \multicolumn{2}{c}{ Production } \\
\cline { 2 - 3 } Type & ha & $\%$ & $\mathrm{t}(\times 1000)$ & $\%$ \\
\hline Clementine mandarin & 23,030 & 32 & 302.5 & 25 \\
Valencia orange & 21,310 & 30 & 500.0 & 41 \\
Navel oranges & 17,630 & 25 & 263.0 & 6 \\
Blood oranges & 3,970 & 6 & 78.0 & 7 \\
Other citrus & 5,370 & 7 & 90.0 & 100 \\
Total & 71,310 & 100 & 1233.5 & \\
\hline
\end{tabular}

Data from MARA, 1988.

Table 3. Age of trees for major citrus types (1985-86). ${ }^{2}$

\begin{tabular}{|c|c|c|c|c|c|c|c|}
\hline \multirow[b]{2}{*}{ Type } & \multirow[b]{2}{*}{ Unit } & \multicolumn{5}{|c|}{ Age (in years) } & \multirow[b]{2}{*}{ Total } \\
\hline & & $0-4$ & $5-9$ & $10-24$ & $25-34$ & $>35$ & \\
\hline $\begin{array}{l}\text { Clementine } \\
\text { mandarin }\end{array}$ & $\begin{array}{l}\text { ha } \\
\%\end{array}$ & $\begin{array}{r}1020 \\
4\end{array}$ & $\begin{array}{r}1493 \\
7\end{array}$ & $\begin{array}{r}15,846 \\
71\end{array}$ & $\begin{array}{r}2,821 \\
13\end{array}$ & $\begin{array}{r}1235 \\
5\end{array}$ & 22,415 \\
\hline $\begin{array}{l}\text { Navel } \\
\quad \text { oranges }\end{array}$ & ha & $\begin{array}{r}2273 \\
14\end{array}$ & $\begin{array}{r}1540 \\
9\end{array}$ & $\begin{array}{r}6,641 \\
40\end{array}$ & $\begin{array}{r}2,761 \\
17\end{array}$ & $\begin{array}{r}3250 \\
20\end{array}$ & 16,465 \\
\hline $\begin{array}{r}\text { Valencia } \\
\text { orange }\end{array}$ & $\begin{array}{l}\text { ha } \\
\%\end{array}$ & $\begin{array}{r}2652 \\
13\end{array}$ & $\begin{array}{r}1235 \\
6\end{array}$ & $\begin{array}{r}7,457 \\
36\end{array}$ & $\begin{array}{r}6,470 \\
31\end{array}$ & $\begin{array}{r}2896 \\
14\end{array}$ & 20,710 \\
\hline $\begin{array}{l}\text { Blood } \\
\text { oranges }\end{array}$ & $\begin{array}{l}\text { ha } \\
\%\end{array}$ & $\begin{array}{r}185 \\
6\end{array}$ & $\begin{array}{r}41 \\
1\end{array}$ & $\begin{array}{r}1,289 \\
41\end{array}$ & $\begin{array}{r}1,142 \\
37\end{array}$ & $\begin{array}{r}456 \\
15\end{array}$ & 3,113 \\
\hline Total & $\begin{array}{l}\text { ha } \\
\%\end{array}$ & $\begin{array}{r}6130 \\
10\end{array}$ & $\begin{array}{r}4309 \\
7\end{array}$ & $\begin{array}{r}31,233 \\
50\end{array}$ & $\begin{array}{r}13,194 \\
21\end{array}$ & $\begin{array}{r}7837 \\
12\end{array}$ & 62,703 \\
\hline
\end{tabular}

${ }^{2}$ Data from ASPAM, 1986. 
their loss of favor in the market, very little planting and grove renewal of these cultivars is taking place.

\section{REGIONAL DISTRIBUTION OF VARIETIES}

The distribution of citrus types by region of production is shown in Table 4. Most of the 'Clementine' mandarin is located in the Seuss $(39 \%)$ and the Oriental $(28 \%)$ regions, as the climate is very suitable for this cultivar and allows production of good-quality fruit. Navels are mostly grown in the Seuss, the Gharb, and the Oriental districts, but 'Valencia' oranges are concentrated in Gharb $(41 \%)$ and Seuss $(34 \%)$. Blood oranges are more suitable for the climate of Gharb. The citrus areas of Tadla and Houz are about equally divided between 'Clementine', navel, and 'Valencia'. 'Clementine' is the dominant cultivar in the Loukkos district $(43 \%$ of total) because it does well on the sandy soils of the region.

\section{FRUIT MARKETING}

Moroccan citrus is produced mainly for export. In 1987-88, nearly $50 \%$ of the total tonnage was exported (Table 5), but export fruit can reach $70 \%$ to $75 \%$ of the total produced, depending on market needs and fruit availability worldwide. 'Valencia' oranges accounted for $\approx 48 \%$ of total exports and 'Clementine' 23\%. The domestic market consumed $32 \%$ of the total production (mostly 'Clementine'), whereas the rest was processed into concentrate juice (Table 5). 'Fruit for processing is unexportable or the result of overproduction. 'Valencia' oranges constituted $\approx 48 \%$ of the tonnage converted to juice and other by-products such as essential oils, pectins, and animal feed, while 'Clementine' mandarins accounted for only $9 \%$. Most of the concentrate is exported to Europe.

Most Moroccan fresh citrus exports go to the European Economic Community, which accounted for $71 \%$ of the total exported in 1987-88 (Table 6). Fully one-third of total exports was absorbed by France and onesixth by West Germany (Table 6). Shipments to Scandinavian countries, Canada, and Saudi Arabia accounted for most of the remaining $29 \%$ of total exports. Much interest is now being devoted to developing new markets, especially with the expansion of the EEC and keen competition from other citrusproducing countries.

\section{PROBLEMS OF CONCERN}

Small fruit size is one of Morocco's most significant problems, especially for the alternate-bearing 'Clementine' mandarin, where small fruit account for $20 \%$ to $50 \%$ of the nonexportable crop. This problem is exacerbated by heavy production during on-years. Poor fruit set is also a problem with this cultivar, and the use of gibberellic acid at 10 to $20 \mathrm{ppm}$ during bloom to increase production is a common practice. Small size of 'Valencia' oranges can also be of concern, but the seasonal magnitude of the problem is unpredictable. Rind blemishes constitute an important cause of low pack-outs of all the citrus types; these blemishes are worsened by strong winds, particularly in the windy areas such as the Seuss valley. Oleocellosis is another major cause of low packout, especially on degreened fruit early in the season. Puffing is a problem mostly on 'Clementine' - particularly late in the season: This defect is aggravated by rain. Regreening is a common problem of 'Valencia' oranges and is most severe in years with hot spring days. It can account for $>40 \%$ of the unexportable fruit.

Psorosis constitutes one of the major virus-related problems of citrus. It is prevalent in old groves and can be found on all cultivars. Exocortis and stubborn are very rare,

Table 4. Citrus distribution (in ha) by region of production (1987-88). ${ }^{2}$

\begin{tabular}{lcrrrrr}
\hline \hline & \multicolumn{5}{c}{ Citrus type } & \\
\cline { 2 - 5 } Region & $\begin{array}{c}\text { Clementine } \\
\text { mandarin }\end{array}$ & $\begin{array}{c}\text { Navel } \\
\text { oranges }\end{array}$ & $\begin{array}{c}\text { Valencia } \\
\text { orange }\end{array}$ & $\begin{array}{c}\text { Blood } \\
\text { oranges }\end{array}$ & Other & Total \\
\hline Souss & 8,910 & 4,210 & 7,250 & 250 & 1,250 & 21,870 \\
Gharb & 1,720 & 4,180 & 8,750 & 1860 & 590 & 17,100 \\
Oriental & 6,420 & 3,110 & 110 & 100 & 1,000 & 10,740 \\
Tadla & 2,020 & 2,830 & 2,470 & 800 & 850 & 8,970 \\
Haouz & 1,480 & 1,330 & 1,000 & 200 & 810 & 4,820 \\
Loukkos & 980 & 580 & 460 & 70 & 170 & 2,260 \\
Other & 1,500 & 1,390 & 1,270 & 690 & 700 & 5,550 \\
Total & 23,030 & 17,630 & 21,310 & 3970 & 5,370 & 71,310 \\
\hline
\end{tabular}

zData from MARA, 1988.

Table 5. Exports, local consumption, and processing of Moroccan citrus by type (1987-88). ${ }^{2}$

\begin{tabular}{|c|c|c|c|c|c|c|c|c|}
\hline \multirow[b]{2}{*}{ Type } & \multicolumn{2}{|c|}{ Exports } & \multicolumn{2}{|c|}{$\begin{array}{c}\text { Domestic } \\
\text { consumption }\end{array}$} & \multicolumn{2}{|c|}{ Processing } & \multicolumn{2}{|l|}{ Total } \\
\hline & $t(\times 1000)$ & $\%$ & $\mathrm{t}(\times 1000)$ & $\%$ & $t(\times 1000)$ & $\%$ & $t(\times 1000)$ & $\%$ \\
\hline Clementine & 135.8 & 23 & 144.5 & 36 & 22.2 & 9 & 302.5 & 25 \\
\hline Navel & 91.3 & 16 & 108.1 & 27 & 63.6 & 25 & 263.0 & 21 \\
\hline Valencia & 279.0 & 48 & 99.7 & 25 & 121.3 & 48 & 500.0 & 41 \\
\hline Other & 75.3 & 13 & 47.1 & 12 & 45.6 & 18 & 168.0 & 13 \\
\hline Total & 581.4 & 47 & 399.4 & 32 & 252.7 & 21 & 1233.5 & 100 \\
\hline
\end{tabular}

${ }^{2}$ Data from MARA, 1988.
Table 6. Moroccan fresh citrus exports by country of destination $(1987-88){ }^{z}$

\begin{tabular}{lcr}
\hline \hline & \multicolumn{2}{c}{ Quantity } \\
\cline { 2 - 3 } Country & $\mathrm{t}(\times 1000)$ & $\%$ \\
\hline France & 195.3 & \\
W. Germany & 85.1 & \\
Great Britain & 56.5 & \\
Holland & 50.1 & \\
Belgium & 27.5 & 71 \\
Total EEC & 414.5 & \\
Scandinavia & 91.9 & \\
Saudi Arabia & 46.2 & \\
Canada & 25.1 & \\
Other & 3.7 & \\
Total non-EEC & 166.9 & 29 \\
Grand total & 581.4 & 100 \\
\hline
\end{tabular}

${ }^{2}$ Data from MARA, 1988.

and tristeza (at least the virulent strain) is believed to be nonexistent. New groves are composed of locally produced trees certified as free of these major virus or virus-like diseases. In recognition of the serious problem caused by virus and virus-like diseases, Morocco has a national citrus grove renewal and expansion program that provides financial incentives to replace old groves with, or plant new groves to, certified trees.

The most common fungus disease is Phytophthora spp. rot of tree roots, trunks, stems, and fruit, especially in wet areas and during wet seasons. Penicillium spp. constitute the major postharvest threat to fruit, especially with the appearance of fungicide-resistant strains.

Insects of concern to the industry include California red scale, mites, aphids, white flies, and Mediterranean fruit fly. The last is more of a problem in the Seuss area as it uses the argan [Argania spinosa (L.) Skeel] as an alternate host, especially during the summer when the argan fruits are mature and citrus fruits are still green and not very susceptible to the fly. In general, control of Mediterranean fruit fly in Morocco is excellent. The semi-endoparasite Tylenchulus semipenetrans is the major nematode attacking citrus in Morocco, but the effect on yield is still unclear.

The fact that both 'Clementine' and navel production peak during the months of November through January is of concern, particularly during heavy production years. Since this is also the season when citrus matures in the other northern hemisphere countries that export citrus, local and export markets are saturated, leading to a substantial drop in price. Efforts are being devoted to diversify the export market by diversification of the cultivar profile. Emphasis is on early and late-producing 'Clementine' clones (as stated earlier) and production practices that lead to excellent internal and external quality. Also, attention is being paid to maintaining a regular supply of citrus in Morocco's major export and domestic markets.

\section{Literature Cited}

ASPAM. 1986. Enquête agrumicole 1985-86. Association des Producteurs d'Agrumes au Maroc, Casablanca, Morocco. 
Burke, J.H. 1967. The commercial citrus regions of the world, p. 118-122. In: W. Reuther, L.D. Batchelor, and H.J. Webber (eds.). The citrus industry. vol. 1. Univ. of Calif. Press, Berkeley.

Devaux, R. 1981. New cultivars of 'Clementine' mandarin in Morocco. Proc. Intl. Soc. Citricult. 1:101-102.

FAO. 1989a. Annual statistics: Citrus fruit, fresh and processed. Food and Agriculture Organization of the United Nations, Rome.

FAO. 1989b. Committee on "commodity problems, Intergovernmental Group on Citrus Fruit, Eighth Session, Montevideo, Uruguay, 11-15 Sept. 1989, Longer term outlook for citrus fruit. Food and Agriculture Organization of the United Nations, Rome.

FAO. 1989c. Committee on commodity prob- lems, Intergovernmental Group on Citrus Fruit, Eighth Session, Montevideo, Uruguay, 11-15 Sept. 1989, National and regional citrus policies. Food and Agriculture Organization of the United Nations, Rome.

MARA. 1988. Bilan de la campagne agrumicole 1987-88. Ministere de l'Agriculture et de la Reforme Agraire, Division de l'Horticulture, Rabat, Morocco. 